\title{
Change agency and urban vulnerability: Theological- ecclesial paralysis or deep solidarity
}

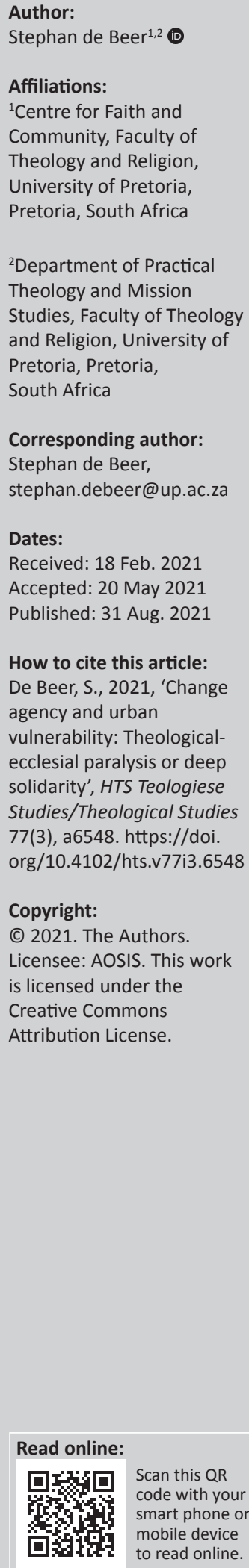

Globally, cities respond differently to their most vulnerable urban populations, notably so during the coronavirus disease 2019 (COVID-19) pandemic. In the City of Tshwane, there seems to be a general paralysis of the church and theological education in relation to urban vulnerability. If the church and theological education are to participate as change agents to help transform urban vulnerability, a deliberate theological praxis and deep urban diaconate in solidarity with the city's most vulnerable realities - are proposed. This is done with reference to Harvey Cox's assertion that the task of the church in the city is that of Diakonos and the provocations of Philippino liberation theologian, Daniel Pilario.

Contribution: This article proposes that urban vulnerability and various responses to it need to be reflected upon as a priority, much more deliberately, considering how the entire urban household (oikos) is at risk.

Keywords: urban vulnerability; urban diaconate; theological praxis; theological education; ecclesial and theological liberation; change agency.

\section{Introduction}

Globally, cities respond differently to their most vulnerable populations, also in the face of the coronavirus disease 2019 (COVID-19). Here, urban vulnerability - referring to vulnerable urban places, people and eco-systems - is framed as a risk to the sustainability of the entire urban household.

In the context of urban vulnerability, this article then considers change agency as the deliberate processes, practices and interventions, aimed at addressing, overcoming and transforming vulnerability into resilience.

The contention of this article is that there is a general paralysis of theological education and the church in relation to urban vulnerability, also in the City of Tshwane. ${ }^{1}$ It argues that such a paralysis flows from the ongoing absence of (1) a deliberate theological praxis focusing on, or immersed in, contexts of urban vulnerability, as well as (2) a deep diaconate connected with urban vulnerability in systematic, strategic and transformative ways. Such a paralysis serves to deepen urban vulnerability, as it expresses a lack of vision, will, resources and agency to help address and overcome diverse forms of urban vulnerability innovatively and decisively.

Some hopeful narratives are retrieved - often not ecclesial nor theological - as clues for theological-ecclesial-diaconal transformation, if it is to participate as change agents in vulnerable urban contexts. Finally, a deliberate theological praxis and deep diaconate are proposed as essential ingredients for (faith-based) change agency, which is able to transform urban vulnerability. This is done with reference to Harvey Cox's (1965:116) assertion that 'the church's task in the secular city is to be the diakonos of the city, the servant who bends himself to struggle for its wholeness and health'.

\section{The primacy of the city's most vulnerable populations and places: A theological and moral imperative}

One of liberation theology's core premises is a preferential option for the poor (Gutierrez 1988:xxv). It considers the well-being of society through the lenses of those who are mostly

1.The City of Tshwane is the name of the metropolitan municipality of which Pretoria forms a part. This is also the administrative capital city of South Africa.

Note: Special Collection: Being a Change Agent in a (Post-) Covid South Africa, sub-edited by Erna Oliver (University of South Africa). 
excluded from society. It considers the faithfulness of the church through the lenses of how faithful the church is to Christ in the poor and the stranger.

An urban theology of liberation will: (1) locate itself with the city's most vulnerable, marginalised and oppressed populations and places; (2) work actively for the liberation of the city's most vulnerable through action, reflection, dialogue, research and activism; and (3) evaluate the well-being or success of the city in terms of how well it does to include vulnerable populations and places meaningfully and sustainably into the life and fibre of the city, in ways that mediate integral liberation and multiple freedoms.

The point of departure of this article therefore is the primacy of the city's most vulnerable populations and places, both as a theological imperative and as a moral and human imperative, ensuring that the weakest among us are bestowed with greater honour in order for the abundance of Christ to be shared equitably.

To ensure the ongoing and full liberation - and therefore integration and participation - of the city's most vulnerable populations in the life of the city, deep change is required. If the church and theological education are largely paralysed, in the face of deep urban vulnerabilities, where will the agency come from to effect such a deep change? Can change agency be fostered in local faith communities and congregations, in more deliberate ways, and what could be the sources of such formational works? Can theological education, generally, and practical theology, more specifically, be a source of liberating change, flowing from deep solidarity with very vulnerable populations? Can such liberating theology be possible without the primacy of deep, embodied solidarity?

\section{Framing urban vulnerability}

Urban vulnerability is defined differently by different people, depending on their vantage point. Globally, cities are home to very vulnerable populations, sometimes even constituting the majority of a city's population. Cities where $80 \%-90 \%$ of the population live in urban slums, characterised by layers of vulnerability, are an example. Cities and associated urban vulnerabilities affect the entire planet (cf. Srinivas 2021).

One definition of urban vulnerability, which features most prominently, is to describe it as the exposure of urban residents (particularly poor populations) to climate hazards and their ability to adapt or mitigate risks in order to reduce negative impacts (cf. Lankao \& Quinn 2011; Rubin 2011; Srinivas 2021).

I consider urban vulnerability in a more holistic manner as described by Birkmann et al. (2013:199-201), considering human-social, physical, cultural, economic, health, environmental and institutional factors. To address, reduce or even overcome urban vulnerability, all these factors - or the totality of the urban household (oikos) - need to be considered simultaneously.
Urban vulnerability is often the result of systemic socioeconomic-spatial exclusions, over shorter or longer periods of time, mediated by policies, planning and priorities that fail to foster radical inclusivity or opt, in a central manner, for the most vulnerable urban places and populations, beyond political or other forms of rhetoric only (cf. also Bhanjee 2019).

It is an expression of people's lack of access to essential sources of livelihood, well-being or freedom, and the lack of resistance of those forces that render people or neighbourhoods vulnerable.

Bohle (2001:3/6) distinguished between internal and external aspects of vulnerability. There are forces or processes external to a person or neighbourhood that determine their conditions and futures, often in spite of them; but there are also internal aspects such as abilities or resourcefulness of persons or neighbourhoods to anticipate, cope with or recover from external pressures; or, the internal inabilities or deficits of persons or neighbourhoods, rendering their vulnerability even more absolute.

Rather concretely, in the Gauteng City-Region or the City of Tshwane, urban vulnerability or vulnerable urban populations could refer to whole regions or neighbourhoods, specific buildings or properties, or specific groups of people or populations. Informal settlement neighbourhoods are often experiencing different forms of vulnerability, partly because of the spontaneous formation of settlements, without pre-planning and formal inclusion in urban structures. Parts of Alexandra Township, for example, are perpetually at risk of flooding and loss of life, when the Jukskei River comes down because of heavy rainfalls.

Many hijacked buildings in Johannesburg or Tshwane have all the characteristics of vulnerability - both physically and in terms of the well-being of the people living there - because of poor or no maintenance, fire hazards or criminal activity.

Specific people groups or populations characterised often by absolute forms of vulnerability - exclusion and marginality are homeless communities, people living with chronic mental illness, people living with disability, certain groups among the LGBTIQ+ communities, impoverished and isolated older persons, young unemployed people, girl children, commercial sex workers, in particular, street workers and those forced into prostitution.

A very tangible example for demonstrating how human, economic, social and environmental vulnerabilities interrelate includes landfill sites in the entire Gauteng CityRegion, which have also become home to poor people who are making a living off the sites. The relationship between urban vulnerability and environmental toxicity in these sites both directly for those living on landfill sites being exposed to their hazardous nature permanently and for surrounding neighbourhoods because of poor air quality - has devastating consequences. 
Urban vulnerability therefore should be understood as multidimensional (i.e. different types of vulnerability as seen above), dynamic (i.e. changing over time), site-specific (i.e. each location differs) and at different scales (from individual or household, to neighbourhood city or even country) (cf. Van Westen 2014).

\section{Vulnerability and resilience}

In a number of definitions, vulnerability and resilience are indicated as two extremes on a spectrum (cf. Birkmann 2006; Birkmann et al. 2013; Bohle 2001; Pelling 2003). Absolute vulnerability will denote multiple forms of exclusion, a lack of access to resources that mediate well-being or freedom and a lack of capacity to resist multiple forces dealing with vulnerability. Resilience, on the other hand, would be 'the capacity of individuals or communities to withstand the impact' (Pelling 2003) of external or internal forces of exclusion, crisis or risk and adaptive mechanisms to address and creatively overcome such forces.

Birkmann et al. (2013) have developed the so-called MOVE framework to understand and address vulnerability. This framework regards vulnerability as exposure to various risks or hazards, susceptibility of persons and communities to vulnerability amidst such risks, fragility of persons or communities, and the lack of resilience to cope or adapt when facing risks (cf. Birkmann et al. 2013:195). Building resilience will therefore have to address conditions that will help reduce exposure to hazards or risks; and in doing so reduce susceptibility and fragility of populations or neighbourhoods to vulnerability, whilst building their capacity to cope, adapt or deal creatively with risks or threatening changes facing them (cf. Birkmann et al. 2013:194). This is, or should be, a very holistic endeavour, addressing social-human, economic, cultural, physical, environmental and institutional elements that contribute to vulnerability.

In the Centre for Faith and Community at the University of Pretoria, we designed a 3-day course entitled 'Approaches to community transformation'. One of the central thrusts in this course suggests that transforming communities is about accompanying communities from vulnerability to resilience, in holistic and integrated ways.

\section{Urban vulnerability - an eco-theological challenge}

If urban vulnerability reduces the ability of the urban oikos thehousehold of humanity, theeconomy and theenvironmentto mediate well-being and freedom; placing human dignity and the integrity of creation at risk; and results from socioeconomic spatial-environmental injustices, it is indeed a theological concern, requiring not only deep theological analysis and reflection, but also theological action. I speak about it as an eco-theological challenge, not in a narrow environmental sense only, but as a theological challenge that involves the totality of the urban household (oikos). This article is not meant to provide a comprehensive eco- theological vision on urban vulnerability, but submits that important work needs to be performed in this regard, both to support systemic transformation that will reduce the conditions that enable vulnerability, and to develop measurable indicators for concrete local transformations of urban vulnerability in the direction of an increasing sense of resilience, flourishing and well-being. The works of people such as Van Schalkwyk (2014), Castillo (2019) and Holden, Nadeau and Porio (2017) need to be considered in this regard, fusing ecological, feminist and liberationist perspectives and exploring implications for local faith-based responses. The challenge is to contextualise these insights in relation to very localised expressions of urban vulnerability.

Vulnerable urban contexts call for radical change. The harshness of urban vulnerability - and oft invisibility and exclusion of vulnerable people and places - requires not aloof forms of theological reflection and action, but the kind of theological praxis that stands in close solidarity with vulnerable people and places, fusing reflection and action, analysis and discernment, allowing for the one to shape the other, with the city's most vulnerable groups as its primary interlocutors.

Without such solidarity - allowing urban vulnerability to be visible, central and disruptive - our theological work will be untransformed. Without such solidarity, deep vulnerabilities will continue to be regarded as inevitable, and our contributions failing to make deep change.

Instead, making urban vulnerability visible in very concrete ways, whilst simultaneously challenging its perceived inevitability, will help prioritise the urban poor, theologically, and help ensure that urban vulnerability also receives a central place on the city's agenda.

The change that vulnerable urban contexts demand, even though urgent, often occurs best when facilitated and effected incrementally, over longer periods, with the ownership and active participation of those most affected (cf. Swilling, Tavener-Smith \& Keller 2015:261-277). Incrementality should not be an excuse to minimise urgency however. Imaginaries of radical urban change - in the direction of greater resilience, freedom and well-being - should be constructed, made to be non-negotiable and then facilitated collaboratively through multiple preventative, protective and reconstructive actions.

I pose the question as to the possible role of theological praxis and deep diaconate as ingredients of urban change agency. As a critical part of the urban citizenry, the church and theological education could potentially contribute as a servant of collaborative processes, which stand in solidarity with urban vulnerabilities, broker tables of collaboration between various sectors in a city and facilitate own resources as contributions towards urban reconstruction.

It requires a complete, rigorous and penetrating assessment and deconstruction of current notions of diaconate or pastoral 
care, as - through a lens of urban vulnerability - the paralysis of church and theological education is severely exposed.

\section{Different cities in response to urban vulnerability during COVID-19 - and the paralysis of church and theological education in the City of Tshwane}

Different cities, globally, respond to urban vulnerability in their midst, rather differently. During COVID-19, the face of vulnerability has often been accentuated, particularly as the well-to-do had ways and means to isolate themselves, leaving the excluded rather visible, for once.

These different approaches varied from harsh marginalisation to innovative protection. Roy (2020) described how the poor in India were marched from Delhi during the hard lockdown imposed by Narendra Modi:

As an appalled world watched, India revealed herself in all her shame - her brutal, structural, social and economic inequality, her callous indifference to suffering... As shops, restaurants, factories and the construction industry shut down, as the wealthy and the middle classes enclosed themselves in gated colonies, our towns and megacities began to extrude their working-class citizens - their migrant workers - like so much unwanted accrual. Many driven out by their employers and landlords, millions of impoverished, hungry, thirsty people, young and old, men, women, children, sick people, blind people, disabled people, with nowhere else to go, with no public transport in sight, began a long march home to their villages... Some died on the way. (n.p.)

As they walked, some were beaten brutally and humiliated by the police, who were charged with strictly enforcing the curfew... A few days later, worried that the fleeing population would spread the virus to villages, the government sealed state borders even for walkers. People who had been walking for days were stopped and forced to return to camps in the cities they had just been forced to leave. (n.p.)

Similar reports came from the Philippines. Pilario (2020) wrote about the socially excluded in the cities and towns of the Philippines:

Now that people have some mobility and can go to work in limited capacities... there will be always people who remain excluded. They are suffering the same hunger and pain as they did during the total lockdown... street people, the sick, the elderly, those living under bridges, those who have no homes. (n.p.)

Coronel (2020) reports how government officials in certain parts of Metro Manila forced shelters, also those run by churches or priests, to close down. In response, a restaurant, two Catholic universities, and a number of churches opened their doors to shelter homeless persons. The De La Salle University opened its sport centre to accommodate 79 homeless people, working with the Divine Word Missionaries.

In Cairo (Al-Youm 2020), as lockdown was enforced, many homeless people and street children were left to their own devises. Fifteen-year old Karim Mohamed is isolated from his friends and support structures:

Before the outbreak, Karim used to go to the al-Fateh Mosque nearby the square for breakfast, lunch and dinner. (n.p.)

Places of worship are shut down, gatherings are not permitted and places where the most vulnerable could wash, eat and congregate are not off limits.

In places like Kampala, Human Rights Watch (2020) reported multiple incidents where vulnerable populations - informal traders, homeless persons and the LGBTIQ+ community were seriously violated:

On March 29 (2020), community residents and police raided a shelter for homeless lesbian, gay, bisexual and transgender youth in Wakiso, outside of Kampala, and beat and arrested 23 people, including shelter residents. (n.p.)

None of the above should be made off as isolated incidents. These are the daily experiences of the city's most vulnerable populations, pre- and during COVID-19. In most instances, vulnerable urban people also lack solidarity from churches and theological institutions, allowing the image of God to be violated on the streets and marketplaces of the world's cities every day.

There are also some examples with signs of hope. The Mayor of London availed 300 hotel rooms for homeless people to self-isolate (Hutt 2020). The Accor Group in Paris provided 600 hotel beds for homeless people, and government in France invested $€ 50000$ (almost R1 billion) (Cook 2020). And by the end of March 2020, 2000 bed spaces for homeless persons were offered in the state of California (Hutt 2020). Not one hotel in Tshwane was willing to avail itself, and I am unaware of any such anywhere in South Africa.

In Paris, the Red Cross expressed its commitment to support government's interventions: 'As in every crisis, the most fragile, the most isolated and destitute will be the most exposed and the most forgotten' (Blanquine 2021:n.p.). They pledged to stand in solidarity with exactly these groups. In Lima, Peru, a traditional bull ring was converted into a homeless shelter during COVID-19 (Ruiz et al. 2020).

These global examples, as in the Tshwane example, serve as signs of hope and lessons to glean from. They prove the possibility for impactful, coordinated responses to overcome urban vulnerability through diverse strategies in which government, civil society and university partners collaborate.

\section{Street homelessness in South Africa: Local responses to urban vulnerability}

The way in which street homeless communities are engaged during COVID-19 is a barometer for how municipalities, the church and institutions generally embrace, or marginalise, vulnerable populations. In South Africa, various 
municipalities responded in various ways to street homelessness, both during and after hard lockdown.

In eThekwini, 1000 people were housed in 10 temporary shelters within two days. In the City of Tshwane, 25 temporary COVID-19 shelters were created, housing 1500 people within 10 days, and doing 12000 health screenings. The City of Johannesburg was not able to create more than five temporary shelters. And in Cape Town, 2000 people were forced into a makeshift shelter in Strandfontein, which immediately drew the ire of homeless communities, human rights activists and the community of Strandfontein, fast evolving into a potential humanitarian disaster. The city was forced to shut down Strandfontein, and only a small percentage of those who were accommodated here were provided with alternative accommodation.

In spite of very constructive collaboration in the City of Tshwane between the municipality, non-governmental organisations (NGOs) and researchers from two universities, in the aftermath of hard lockdown, many of the temporary shelters closed down, with the city failing to sustain its commitment to a post-lockdown strategy drafted in collaboration with the research community and the Tshwane Homelessness Forum (cf. Ndlazi 2021). It leads to the question of why lessons learnt during COVID-19 are not optimally taken advantage of in shaping alternative urban futures. Could it indeed be that the city's most vulnerable populationswho require deliberate and additional support for their viable inclusion in the city's fabric - are regarded as lesser citizens of the city, not 'deserving' of being prioritised?

It became clear that instances where government, NGOs and the research community collaborated, evidence-based interventions were made possible and vulnerable communities were welcomed into spaces where significant alternatives were available. These hopeful signs should become the imaginaries that determine our policy and investment priorities.

COVID-19 not only revealed serious fault lines in how vulnerable urban populations are excluded from policy and strategic investment, and how both state and church are not really geared towards ongoing or crisis interventions, but also offered new opportunities for collaboration and innovation, and progressive NGOs, citizen groups and academics modelled possible interventions that could become the 'new normal', if the political and moral will existed (cf. De Beer 2020b).

\section{Community action networks, local ecumenical action networks and other brave new partnerships}

A very innovative and exciting response - to mobilise and connect good will and resources locally, in order to address local vulnerabilities - was the creation of Community Action Networks (CANs). Scheepers, Lakhani and Armstrong (2020:n.p.) described CANs in the following way: 'Community Action Networks in South Africa bring residents from varied backgrounds into collective action to find solutions to COVID-related issues'.

With reference to their own CAN, in the neighbourhood of Woodstock, they wrote (Scheepers et al. 2020):

[A]s a CAN we are trying to experiment - as are a host of other organisers and activists - with new and old ways of community building so that we might create transformation in our neighbourhood that lasts beyond our response to the pandemic. (n.p.)

What started in one neighbourhood was soon spreading across the City of Cape Town, from Woodstock to places such as Constantia, Muizenberg and Khayelitsha. The concept also spread to other parts of the country because its efficacy was soon becoming clear. By July 2020, there were already more than 100 CANs across the Gauteng City-Region (Heywood 2020).

Drawing from the examples and templates of CANs, the South African Council of Churches motivated its constituencies to form what it called Local Ecumenical Action Networks (LEANs). According to Craig Stewart, who was closely involved in the framing of the LEAN vision and template, more than 100 LEANs were formed across the country, including 'brand new' formations, 'existing groups that took on a new shape', very active LEANs, 'whilst others didn't get much further than starting'. ${ }^{2}$

In some instances, collaborations deepened significantly, for example, between different academic disciplines engaging homelessness in Tshwane through an evidence-based approach. In eThekwini, different faith formations found remarkable ways to collaborate in supporting homeless shelters.

Across the country, a number of temporary shelters became permanent housing facilities, and two new housing projects for older homeless persons were opened during hard lockdown in the City of Tshwane, seeing concrete collaboration between a social housing company and a social development agency. Such permanent housing options for vulnerable groups during COVID-19 serve as success stories arising from collaborative conversations and partnerships, committed to long-term, sustainable and local solutions.

In the majority of cases where such innovative and transformative responses to urban vulnerability were seen, government played an enabling and not a stifling role. The role of government 'is to help create the conditions where good outcomes are more likely to emerge' (Brown 2019).

\section{The paralysis of church and theological education in the City of Tshwane}

Although my assertion might be met with contention in many quarters, I acknowledge that COVID-19 in the City of Tshwane, especially from the perspective of particularly 2.From e-mail correspondence with the author of this article, enquiring about the status of LEANs. 
vulnerable populations, revealed a general paralysis of church and theological education, in response. I say 'general' paralysis because in isolated instances, there were remarkable outpourings of support, demonstrating 'unusual kindness' (cf. De Beer 2020a).

Over a period of 10 days in the City of Tshwane, 25 temporary COVID-19 shelters were opened for homeless persons. Elsewhere, I wrote a piece that was entitled 'The miracle of Tshwane' (De Beer 2020a), because of the remarkable collaborative effort undertaken to house homeless persons in a short space of time.

Eleven of these shelters were run from the facilities of churches or faith-based organisations. Although the embrace of homeless persons by these churches and faith-based organisations (FBOs) was heartening and often mutually lifechanging, the fact that only 11 shelters were opened from church bases, in a city the size of Tshwane with literally thousands of churches lining its streets, raises urgent questions. It makes one think about Taylor's (1996) conclusion that only a small remnant actually responds faithfully to the gospel.

A number of churches considered opening their facilities but sought guarantees that their properties would be safe and that homeless persons will not want to stay there permanently. Instead of considering long-term journeys, whereby they could become partners in the effort to overcome street homelessness more decisively, they took a short-term view and mostly opted out. Many churches used government's closure of worship spaces during hard lockdown as a reason for why they could not provide care to the most vulnerable among us. They were waiting for government to give them a mandate to care for the poor.

There were, of course, churches that did not open their facilities, but invested generously - financially or in the form of other resources - to assist those who fell through the cracks when lockdown disabled people from accessing their normal sources of income or livelihoods. One church opened its facility as a central resource hub from where donations could be distributed to shelters across the city. Township churches across Tshwane had to deal with the reality of hunger and food insecurity, but they themselves being ill-resourced could not necessarily respond as boldly and generously as they would want to. Solidarity between resource-poor and resource-rich churches also lacks considerably, and - whilst we know it - the pandemic highlights our disconnectedness from each other under a magnifying glass.

The isolation of the city's vulnerable was often more accentuated during this time, as places of refuge where they would ordinarily find comfort now shut its doors. It has been relatively easy for well-resourced churches to move their worship events online, but for the majority of worshippers in poor neighbourhoods of Tshwane, this was not similarly possible. Moreover, whilst some lauded the possibilities of virtual worship, the ways in which those in need of care were often locked out revealed a theological disposition void of deep solidarity.

Pilario (2016) says:

Bereft of social, political, and economic networks, the Eucharist is the poor's only connection that works ... the Eucharistic table is a symbol of hope for the battered, the lost, the hungry, the broken, the excluded, the poor. (n.p.)

Taking away this communal and sacramental experience, which proclaims and embodies God being with us, as we gather in communion, is like taking away the only connection to life for those facing absolute vulnerability.

In the face of deep urban vulnerability, there are places and people in need of deep, embodied solidarity, to resist lifedenying forces of this and other pandemics. The sacramental solidarity of practising presence, in a challenging time of physical distancing and self-isolation, revealed a theological poverty that now demands urgent attention.

I acknowledge that theological education lost a significant opportunity to shape a new generation of leaders, able to respond to catastrophe in appropriate, tangible and lifeaffirming ways. Instead of discerning innovative ways of practising our vocation together in response to COVID-19, particularly, and urban vulnerability, more generally, theological schools by and large also shut our doors, went online and prevented students, generally speaking, from amazing learning experiences at the coal face of humanity. Encouraged to research and write more during this time, it revealed a theological posture that finds it possible to write from discarnate places, instead of urging deep solidarity that would transform the ways in which we teach and write.

In shelters across the city, there were students, from time to time, acting as shelter managers, social workers or health volunteers. Sadly, mostly they came from other disciplines as diverse as accounting and architecture - whilst theological students and educators kept themselves at a safe distance. How does one foster solidarity - through our theological education - in the face of debilitating vulnerability without being in solidarity ourselves? I raise the question from two perspectives: on the one hand, it seems as if the current theological education system fails to understand as part of its mandate to produce 'frontline workers' able to confront death in vulnerable urban places; on the other hand, students of theology and ministry themselves seem to lack a desire to be seen as 'frontline workers', unlike health workers, for example, raising serious questions, about the nature of vocation.

\section{Urban vulnerability, theological praxis and urban diaconate}

The complexities and life-denying realities of urban vulnerability, in its multi-layered expressions, call for deliberate, sophisticated, well-reflected and strategic responses. 
I lament what I call the absence of deliberate theological praxis and deep urban diaconate in relation to urban vulnerability. Obviously, I generalise, as there are profound examples to the contrary. But, generally speaking, I argue that such an absence contributes to the reinforcement of lifedenying urban vulnerabilities.

On the other hand, I hold that a deliberate theological praxis deeply connected to specific urban populations and places facing exclusionary and life-denying vulnerabilities, and urban diaconal responses flowing from that might provide the substance for (faith-based) change agency required in such contexts.

Iacknowledge, namely that-in the face of urban vulnerabilitya theological praxis needs to be nurtured, which is deliberately immersed in conditions of such vulnerability, and shaped in its orientation, commitments, reflections and solidarities, by those who experience the harshness of urban vulnerability first hand.

Hundreds of churches are present in contexts where urban vulnerability is rife. Their presence, sadly, does not necessarily guarantee the development of an intentional theological praxis, connected to and transforming urban vulnerability. Instead, their presence is often simply recycling ecclesial rituals and practices a-contextually, hardly expressing the depth and cry of vulnerability they are surrounded with. Peddling platitudes will not transform vulnerable communities, but indeed serves only as religious opium to pacify the people.

When I speak about theological praxis, I speak about the interplay between reflection and action, socio-ecclesial analysis and deconstruction, and creative and provocative imagination of something radically new, grounded in a spirituality of deep change. I consider theological praxis as 'a praxis of solidarity' that is 'inspired by the gospel' and working 'in the interests of liberation' (Gutierrez 1988:xxx). It is not neutral nor a-political, as it is in solidarity with places and people discarded, marginalised and rendered invisible, by urban political processes. It is a deeply discerning praxis, together with those facing vulnerable conditions in existential, detrimental and sometimes deadly ways.

Nurturing, very intentionally, such a theological praxis in contexts of urban vulnerability - putting on hold our preconceived ideas of what good news should look like, and through which wineskins it should be mediated - might give us a chance to discern and birth socio-diaconal pastoral responses, which are much more appropriately and deeply connected to urban vulnerability.

I lament the general absence of a deliberate theological praxis in places of urban vulnerability, because such a praxis can start to articulate and design new socio-diaconal and pastoral responses, not yet seen. Whilst the church engages socially or diaconally, it often does so without sound social analysis, lacking tools for deep theological reflection, replacing strategic action with ad hoc relief, and generally, lacking longterm, humble and costly solidarity. Instead of those experiencing vulnerability becoming the central agents of change, we often centre our own relief work rather. If our urban diaconate is only about making the pain a little bearable, and postponing the inevitability of death with a few more months, it fails to imagine with the prophets of old rebuilt walls, repaired streets, overcoming of vulnerability and liberation of the oppressed.

I acknowledge that shallow or unreflective diaconal form, void of deep theological praxis, is reflective of our theological education. Should solidarity of the kind proposed here be embodied in the curriculum, postures and pedagogies of theological education and theological educators, urban vulnerability will be engaged through radically different diaconal and pastoral forms.

Fostering change agency in contexts of urban vulnerability, at least in faith communities, needs to be deliberate about a theological praxis and urban diaconate that is contextually appropriate, in deep solidarity with urban vulnerabilities, and grounding itself in a spirituality of urban liberation or transformation, in which vulnerable people or places become our central guides.

\section{A transformative urban diaconate}

Although there is much debate in diaconal discourse about how contemporary understandings of diaconate are not necessarily consistent to the original use of the Greek term diakonia, here I will not dwell on that debate (cf. Latvus 2017). Instead, I consider diakonia as 'a social and contextual construct' (Latvus 2017:98), in the way described by Latvus, and consistent to, what he calls, 'the old and truly original task of the church' (Latvus 2017:98) which is 'to love the other, open closed doors, make communities inclusive and work against oppressive structures' (Latvus 2017:4). It is a caritative and justice-seeking diaconate that has evolved over time as a 'reaction against abused and mistreated groups' (Latvus 2017:98), seeking to be faithful to the Christ who, in Mark, identifies himself ultimately as diakonos.

As an evolving concept and 'a social and contextual construct', I therefore propose that we fundamentally revisit our notion or praxis of an urban diaconate, if we are to engage constructively transformatively in vulnerable urban contexts in contemporary African societies. Tetty and Nel (2020) have reflected on such a transformational diaconal praxis as belonging to the core of truly missional congregations.

The kind of change required in contexts of urban vulnerability includes uprooting unjust and exclusionary urban systems and arrangements, whilst building and modelling new more just, inclusive and liberating - systems and arrangements, until it takes root. These are not ad hoc charitable processes, but evidence-based and measurable 
interventions, over long periods of time, with multiple partners, to effect deep change.

Here is the question: how many forms of urban diaconate in the South African context are we aware of that are actually engaging this dual challenge, of uprooting systems and building new ones, in ways that are concrete, strategic and measurable? Unless our diaconal intentions are such, they will hardly reflect the inaugural mandate of Jesus in Luke 4 to be good news to the poor and to liberate the oppressed - as they will continue to treat symptoms through short-term relief, thereby having accepted the inevitability of the status quo.

The World Council of Churches (2013) describes diakonia as:

Service that makes the celebration of life possible for all. It is faith effecting change, transforming people and situations so that God's reign may be real in the lives of all people, in every here and now. (p. 108)

Diakonia, in their definition, is transforming people, places and situations in ways that overcome death-dealing conditions. It is diaconal ministry that includes 'comforting the victim' and 'confronting "the powers and principalities" (Ephesians 6:12)' (Ham 2013:7).

Ham (2013) speaks about such a transformative diaconate in this way:

It must heal the victim as well as the one who victimizes. It is a radical spirituality of struggle and commitment for transformation of sinful social structures and for the liberation of their victims. (p. 6)

The deafening silences (of word and deed) of the majority of local churches and theological education in the City of Tshwane, and elsewhere in South Africa, in response to life-denying urban vulnerabilities, belie something of a lost vocation. When people with disabilities are denied their grants because the relevant department ran out of money; people queueing for their social relief grants are pepper-sprayed by law enforcement agencies; and very vulnerable people are evicted from their homes in the middle of hard lockdown, in breach of COVID-19 regulations, in the middle of winter; one hears hardly a whisper from the ecclesial and theological corridors of power. Perhaps, our lacks of solidarity have removed us to far from where the cries of urban vulnerability grow louder by the day.

Transformational diaconia extends beyond the church seeking to end suffering and injustice, however. It rather seeks to build up communities in order for people to practise own agency in dealing with life-denying forces. Or, it comes alongside those who already stand tall in the face of death, refusing to succumb, learning from them and being transformed into a different kind of servanthood in which we are not central but supportive companions.

\section{The 'bending servant' struggling for urban wholeness: Transforming urban vulnerability}

A transformative urban diaconate will go beyond a charitable approach to urban vulnerability, seeking rather to transform urban vulnerability into resilient, viable and sustainable urban forms of living - indeed, indicating measures of wellbeing and wholeness not known before the diaconal intervention(s).

Danny Pilario (in an interview with Justaert 2012) made a case for returning to the 'rough grounds' of a 'praxis approach'. I take it as a call to do theology in the 'rough grounds' of messy urban contestations and life-denying vulnerabilities, there to discern and animate irruptions of good news, concretely:

The rough grounds... are the locus from which all theology should start. It is also the place where all theology ends. For God chose to locate Him/Herself on the rough grounds, among the margins of society. (n.p.)

I submit that our diaconal response to urban vulnerability should depart from a posture of immersed solidarity, should help animate small acts of kindness and support as well as larger interventions demonstrating measurable transformation. Death requires not whimsical acts of piety only but bold confrontations, both arresting deadly forces and calling forth life.

In exploring a transformational urban diaconate, immersed in the 'rough grounds', I concur with Dulles (2002:84), asserting the importance of the church recognising herself as part of 'the total human family', with a mandate, like Christ himself, not to be served but to serve. Dulles (2002:87) speaks about a 'secular-dialogic' ecclesiology in which the world is the locus of our theological reflection or action, and our theological praxis is in ongoing dialogue with many others. The moment we understand the church as part of 'the total human family' changes the shape of how we do theology.

The church as a servant 'must share in the secular problems or ordinary human life, not dominating, but helping and serving' (Bonhoeffer 1971:382; cf. also Kgatle 2019:71-83). Winter (1963:55) speaks about a servant church - in The New Creation as Metropolis - that is 'no longer an institutional structure of salvation alongside the worldly structures', but rather a 'community within the worldly structures', engaging with humanity 'in the struggle against the powers of evil'. It is a church not aloof from humanity and the struggles of the city, but in deep solidarity, as part of 'the total human family', working to discern, erect and celebrate signs of the new creation in the contemporary and unfolding metropolis.

Building on the work of Winter and others, in his 1965 classic, The Secular City, Harvey Cox goes even further, articulating it as such: '[T] he church's task in the secular city is to be the diakonos of the city, the servant who bends himself 
to struggle for its wholeness and health' (Cox 1965:116) (emphasis mine). This line of Cox's could be the subject of prolonged meditation, with the potential to animate innovative and radical forms of servanthood, not ordinarily evident in our mediocre ecclesial landscapes. A 'servant who bends himself to struggle' for the 'wholeness and health' of the city is a rather poignant and visual image - it speaks of a Christ-like solidarity, bending under the many crosses of urban vulnerability placed upon her shoulders, holding on with many others, for the sake of wholeness, health and well-being, particularly for those parts of the city excluded from such.

It makes me think about my dear friend, Jember Teferra, ${ }^{3}$ an Orthodox woman of faith, who recently died, but laid down her life many years ago as she tirelessly served in the slums of Addis Ababa. Jember and the organisations she created accompanied the poorest communities of her beloved city, brokering all their resources and networks in the interest of communities experiencing absolute forms of vulnerability, very strategically, until measurable evidence of change became visible - in areas ranging from healthcare, water and sanitation, housing, early childhood development, youth care, care of the elderly and people living with disabilities. Her faith did not set itself apart from the city, but found expression in depth of servanthood, working for the 'wholeness and health' of her city. Theirs is a transformative urban diaconate that literally rebuilt communities one block and system at a time.

It is my contention that the majority of ecclesial forms today, and even the ways in which we educate (practising) theologians of the future, fail to heed the calls of Bonhoeffer, Dulles, Winter or Cox, or the examples of Jember Teferra and others like her. Their calls to become servants in deep solidarity with human frailty and vulnerability are seldom heeded.

\section{Healing urban fractures through the lens of transformational diaconal service}

What I propose is a transformational urban diaconate (or socio-diaconic pastorate), which is fully committed to 'healing urban fractures' (Cox 1965:114-125). That is the purpose of the urban diaconate according to Cox - to heal urban fractures in order to mediate an increasing sense of urban wholeness, particularly in the most vulnerable urban places and amongst the most vulnerable urban populations. Elsewhere, I suggested (De Beer 2018:):

We need to vigilantly develop tools to discern the fractures, responsive spiritualities, and appropriate and bold strategies, networks and resources to overcome fractures. This would imply a deep and caring presence in fractured places, abandoned by state, market or church. (p. 37)

3.Jember Teferra (1943-2021) was an Ethiopian community organiser community developer and faith-based leader, who belleved in bottom-up urban development. She founded an organisation called integrad Development Project (IHA-UDP), a project committed to the regeneration of urban slums through the active involvement and priorisation of beneficiary communities themselves. Later, she founded the Birhan Social Development College, providing training and education to community development workers.
Connected to places of urban vulnerability, I propose to create 'multiple centres in what was deemed marginal; make visible what dominant narratives sought to hide; and connect these "new centres" to build synergy and consensus from below' (De Beer 2018:37). It is the political process of making vulnerable visible, centring vulnerable places and people as priority and organising and connecting such centres of action, into movements of urban change, from below. This, however, requires a different ecclesial form, and a different theological pedagogy. It asks for a shifting 'geography of reason', which will allow the city's most vulnerable systems, people and places to transform the way we do and think theology.

\section{Conclusion}

This article sought to frame urban vulnerability as an ecotheological challenge. It argued that immersed theological praxis and deep urban diaconate are two prerequisites for faith-based change agency, able to transform urban vulnerability. It lamented, however, a theological-ecclesial paralysis in relation to urban vulnerability, to such an extent that even diaconal acts are unable to facilitate change, as they often merely serve to sustain (and protect even) the status quo.

Instead, it calls for deep theological and ecclesial solidarity with vulnerable urban communities, allowing their cries to shape our theological thinking and action. It suggests the church as 'bending servant', struggling for urban wholeness through healing urban fractures.

For such an urban diaconate to unfold - able to contribute in ways that will transform urban vulnerability - our very notion and forms of diaconate need to be transformed, as well as the ways in which we educate future leaders for Africa's urban contexts.

In the 'rough grounds' of urban vulnerability, our diaconal forms will have to look, feel and smell like the contexts we seek to serve in. Transforming urban vulnerability requires more radical forms of solidarity, subversive action to outwit bad power, dismantling of unjust structures, erection of bold alternatives to the status quo, and, at times, hopeful-humble revolt.

If urban vulnerability truly deals death, we cannot but become wiser and shrewder in how we engage, arrest and overcome it - through more strategic and collaborative approaches, which are evidence-based, measurable and having the future in mind; and, through more subversive political approaches, which expose, dismantle and replace edifices of death-dealing power.

\section{Acknowledgements Competing interests}

The author declares that he has no financial or personal relationships that may have inappropriately influenced him in writing this article. 


\section{Author's contributions}

S.d.B. is the sole author of this research article.

\section{Ethical considerations}

This article followed all ethical standards for research without direct contact with human or animal subjects.

\section{Funding information}

This research received no specific grant from any funding agency in the public, commercial or not-for-profit sectors.

\section{Data availability}

Data sharing is not applicable to this article as no new data were created or analysed in this study.

\section{Disclaimer}

The views and opinions expressed in this article are those of the author and do not necessarily reflect the official policy or position of any affiliated agency of the author.

\section{References}

Al-Youm, A.-M., 2020, 'How coronavirus is impacting Egypt's homeless', Egypt Independent, 01 April, viewed 09 January 2021, from https://egyptindependent. Independent, 01 April, viewed 09 January 2021, from https://
com/photos-how-coronavirus-is-impacting-egypts-homeless/.

Bhanjee, S., 2019, 'Urban (un)planning and social vulnerability in the context of rapid urbanization and data constraints: A quantitative study of Dar es Salaam, Tanzania', Unpublished PhD in Urban and Public Affairs, University of Louisville, Louisville, KY, viewed 08 February 2021, from https://doi.org/10.18297/etd/3254.

Birkmann, J., 2006, 'Measuring vulnerability to promote disaster-resilient societies: Conceptual frameworks and definitions', in J. Birkmann (ed.), Measuring vulnerability to natural hazards: Towards disaster resilient societies, pp. 9-54, United Nations University Press, Tokyo.

Birkmann, J., Cardona, O.D., Tibaduiza, M.L.C. \& Barbat, A.H., 2013, 'Framing vulnerability, risk and societal responses: The MOVE framework', Natural Hazard 67(2), 193-211. https://doi.org/10.1007/s11069-013-0558-5

Blanquine, M., 2021, Report French Red Cross - January 2021, viewed 04 February 2021, from https://www.globalgiving.org/projects/soutenez-la-croix-rougefrancaise/reports/.

Bohle, H.G., 2001, 'Vulnerability and criticality: Perspectives from social geography', IHDP update 2/2001. Newsletter of the International Human Dimensions Programme on Global Environmental Change: $1 / 6-6 / 6$.

Bonhoeffer, D., 1971, Letters and papers from prison, SCM Press, London.

Brown, A., 2019, 'The mindset shift emerging from local government', Centre for Public Impact, 30 May, viewed 08 April 2021, from https://www. centreforpublicimpact.org/insights/mindset-shift-emerging-local-government.

Castillo, D.P., 2019, An ecological theology of liberation: Salvation and political ecology, Orbis Books, Maryknoll, New York, NY.

Cook, C., 2020, 'France houses its homeless to combat COVID-19', posted 19 March 2020, viewed 18 January 2021, from https://www.aa.com.tr/en/europe/francehouses-its-homeless-to-combat-covid-19/1772011\#.

Coronel, S., 2020, 'Philippines: Covid-19 will devastate the poor', The Interpreter, 24 March, viewed 17 January 2021, from https://www.lowyinstitute.org/theinterpreter/philippines-covid-19-will-devastate-poor.

Cox, H., 1965, The secular city: Secularization and urbanization in theological perspective, Princeton University Press, Princeton, NJ.

De Beer, S. (ed.), 2018, Just Faith: Glocal Responses to Planetary Urbanisation, in HTS Religion \& Society Series Volume 3, pp. i-364, AOSIS, Cape Town.

De Beer, S., 2020a, 'Homelessness and Covid-19: The miracle of Tshwane', Spotlight Africa, 23 April, viewed 17 January 2021, from https://spotlight.africa/2020/04/23/ homelessness-and-covid-19-the-miracle-of-tshwane/.

De Beer, S., 2020b, 'Homelessness and Covid-19 in the City of Tshwane: Doing liberation theology undercover - A conversation with Ivan Petrella', HTS Teologiese Studies/Theological Studies 76(1), a6209. https://doi.org/10.4102/hts.v76i1.6209

De Beer, S., 2020c, 'Homelessness and Covid-19: Political, institutional and theological capacities and priorities', Spotlight Africa, 15 April, viewed 05 May 2020, from https://spotlight.africa/2020/04/15/homelessness-and-covid-19-politicalinstitutional-and-theological-capacities-and-priorities/.
Dulles, A., 2002, Models of the church, Image Books/Doubleday, New York, NY. Gutierrez, G., 1988, A theology of liberation, Orbis Books, Maryknoll, New York, NY.

Ham, C., 2013, 'Transformative diakonia in a rapidly changing world', Lecture hosted by Stichting Rotterdam, Utrecht, Netherlands, 11 December 2013.

Heywood, M., 2020, 'Tackling hunger with community action networks', Daily Maverick, 02 July, viewed 18 January 2021, from https://www.dailymaverick. co.za/article/2020-07-02-tackling-hunger-with-community-action-networks/.

Holden, W., Nadeau, K. \& Porio, E., 2017, Ecological liberation theology: Faithbased approaches to poverty and climate change in the Philippines, Springer, Cham.

Human Rights Watch, 2020, 'Uganda: Respect rights in COVID-19 response', 01 April, viewed 15 January 2021, from https://www.hrw.org/news/2020/04/02/ugandarespect-rights-covid-19-response\#.

Hutt, 2020, 'This is how cities help homeless people self-isolate', World Economic Forum, 24 March, viewed 08 January 2021, from https://www.weforum.org/ agenda/2020/03/homeless-self-isolation-cities-coronavirus/.

Justaert, K., 2012, 'Interview with Daniel Pilario Franklin', Newsletter CLT 3, November 2012, viewed 04 February 2021, from https://theo.kuleuven.be/en/research/ centres/centr_lib/pilario-interview.pdf.

Kgatle, M.S., 2019, 'Diakonos and Doulos as concepts of true discipleship in Mark 10.43-44. A social scientific reading', Journal of Pentecostal Theology 28(1), 71-83. https://doi.org/10.1163/17455251-02801006

Lankao, P.R. \& Qin, H., 2011, 'Conceptualizing urban vulnerability to global climate and environmental change', Current Opinion in Environmental Sustainability 3(3), 142-149. https://doi.org/10.1016/j.cosust.2010.12.016

Latvus, K., 2017, Diaconia as care for the poor? Critical perspectives on the development of caritative diaconia, Kirkon tutkimuskeskus, Kuopio.

Ndlazi, S., 2021, 'Organizations for homeless accuse Tshwane of tardiness, empty promises', Pretoria News, 08 February 2021, viewed n.d., from https://www.iol. co.za/pretoria-news/news/organisations-for-homeless-accuse-tshwane-oftardiness-empty-promises-d76bd112-ac6d-4228-9074-a07719326b43.

Pelling, M., 2003, The vulnerability of cities. Natural disasters and social resilience, Earthscan Publications, London.

Pilario, D., 2016, 'The Eucharist and the poor: How does the recent magisterium speak of the Eucharist', Unpublished lecture: International Eucharistic Congress Theological Symposium, Cebu City, 20th January.

Pilario, D., 2020, 'The socially excluded', Famvin, 25 June, viewed 08 January 2020, from https://famvin.org/en/2020/06/25/the-socially-excluded/.

Roy, A., 2020, 'The pandemic is a portal', Financial Times, 03 April, viewed 08 December 2020, from https://www.ft.com/content/10d8f5e8-74eb-11ea-95fefcd274e920ca.

Rubin, M., 2011, Reducing the vulnerability or urban slum dwellers in the Southern African region to the impact of climate change and disasters, Concept paper, Prepared for Urban Landmark, s.l.

Ruiz, L.A., Falcón, D.B., Fahsbender, J., Jha, P., Ramadhan, E., Sandhu, R. et al., 2020, 'Beyond temporary shelters: Protecting homeless populations during and after the COVID-19 pandemic in the Municipality of Lima', SPSG Memo to the the COVID-19 pandemic in the Municipality of Lima', SPSG Memo to the
Government of the Municipality of Lima; drafted by graduate students from the Government of the Municipality of Lima; drafted by graduate students from the Harvard University, 31 July 2020, viewed 15 January 2021, from https://epod.cid. harvard.edu/sites/default/files/2020-08/SPSG\%20Memo\%20-\%20Lima\%20 Municipality.pdf.

Scheepers, E., Lakhani, I. \& Armstrong, K., 2020, 'Making a Community Action Net(work): Organising in the times of COVID-19', 15 May, viewed 18 January 2021, from https://www.openglobalrights.org/organising-in-the-times-ofCOVID-19/.

Srinivas, H., 2021, 'Cities and urban vulnerability in the context of urban environmental management', GDRC Research Output - Concept Note Series E-125, Kobe, Japan: Global Development Research Center, viewed 17 August 2021, from http://www. gdrc.org/uem/disasters/cities-vulnerability.html.

Swilling, M., Tavener-Smith, L. \& Keller, A., 2015, 'Rethinking incremental urbanism Co-production of incremental informal settlement upgrading strategies', in M. Van Donk, T. Gorgens \& L. Cirolia (eds.), Pursuing partnership-based approaches to incremental upgrading in South Africa, pp. 261-277, UCT Press, Cape Town.

Taylor, G., 1996, Remnant voices: Sermons and reflections from the inner city, Salty Print, Cape Town.

Tettey, S.F.K. \& Nel, M., 2020, 'Transformational diaconia as educative praxis in care within the present poverty-stricken South African context', HTS Teologiese Studies/Theological Studies 76(2), a5666. https://doi.org/10.4102/hts.v76i2.5666

Van Schalkwyk, A., 2014, 'Space, place and ecology: Doing ecofeminist urban theology in Gauteng', HTS Theological Studies 70(3), 01-13. https://doi.org/10.4102/hts. v70i3.2767

Van Westen, C.J., 2014, 'Vulnerability', in Caribbean handbook on risk information management, Chapter 5.3, viewed 08 February 2021, from http://www.charim. net/methodology/53.

Winter, G., 1963, The new creation as metropolis, Macmillan, New York, NY.

World Council of Churches (WCC), 2013, Theological perspective on diakonia in the twenty first century, WCC 10th Assembly, Switzerland WCC, Geneva. 